\section{Lembaran Sejarah}

\title{
Dualisme Pajak di Jawa: Administrasi Pajak Tanah di Wilayah Vorstenlanden pada Masa Kolonial, 1915-1942
}

\author{
ABDUL WAHID \\ Universitas Gadjah Mada
}

\begin{abstract}
Land tax (landrent) was first introduced by British Ruler, Thomas Raffles in 1811/1812, but was later retained by the Government of the Dutch East Indies until the end of its power in 1942. The long history of applying this tax has led to various dynamics from continuous administrative reforms to socio-political resistance from the taxpayer (community). In general, the application of land tax adapted to local economic and political conditions to make it work effectively and efficiently. In the autonomous region of vorstenlanden, the application of land tax became the pull out field of political authority between the Dutch East Indies Colonial Government and the traditional Governments of the Yogyakarta and Surakarta palaces, both of which share political and administrative powers in their respective territories. On the one hand this condition leads to dualism administrative, because the land tax operates as a central tax and local tax, thus potentially causing double tax burdens for local communities. This article seeks to critically examine how the pull out of land tax administration in vorstenlanden and how far the tax became part of the political relations of the colonial state with the indigenous traditional state.
\end{abstract}

\footnotetext{
Abstrak

Pajak tanah (landrent) diperkenalkan pertama kali oleh Penguasa Inggris, Thomas Raffles pada tahun 1811/1812, namun kemudian dipertahankan oleh Pemerintah Hindia Belanda hingga akhir kekuasaanya di tahun 1942. Sejarah panjang penerapan pajak ini telah memunculkan berbagai dinamika mulai dari reformasi administratif berkelanjutan hingga resistensi sosial politik dari pihak wajib pajak (masyarakat). Secara umum, penerapan pajak tanah disesuaikan dengan kondisi ekonomi dan politik setempat untuk membuatnya bisa berjalan dengan efektif dan efisien. Di wilayah otonom vorstenlanden, penerapan pajak tanah menjadi medan tarik ulur kewenangan politik antara Pemerintah Kolonial Hindia Belanda dan Pemerintah tradisional Kraton Yogyakarta dan Surakarta, yang keduanya sama-sama memiliki kewenangan politik-administrasi di wilayahnya masing-masing. Kondisi ini di satu sisi menyebabkan timbulnya semacam dualisme administrasi, karena pajak tanah beroperasi sebagai pajak pusat sekaligus pajak lokal, sehingga berpotensi menimbulkan terjadinya beban pajak ganda bagi masyarakat setempat. Artikel ini berusaha mengkaji secara kritis bagaimana tarik ulur administrasi pajak tanah di vorstenlanden dan sejauhmana pajak tersebut menjadi bagian dari relasi politik negara kolonial dengan negara tradisional pribumi.
}

Keywords: land tax; fiscal administration; colonial administration; Vorstenlanden

Kata kunci: pajak tanah; administrasi fiskal; administrasi kolonial; Vorstenlanden 


\section{Pendahuluan}

Kebanyakan literatur menyebutkan bahwa pajak tanah atau landrent diperkenalkan pertama kali di Jawa oleh Thomas Stamford Raffles, sewaktu dia menjadi Gubernur Jenderal Pemerintahan Inggris dari tahun 1811-1816. Dasar yuridis dari pajak baru ini adalah klaim Inggris sebagai pengganti penguasa Jawa sebelumnya, terutama Mataram dan tentu saja VOC. Berdasarkan klaim tersebut, Pemerintahan Inggris menguasai semua tanah di Jawa dan para petani merupakan peminjam atas tanah tersebut. Oleh karena itu, mereka harus membayar sejumlah uang tertentu senilai sekitar seperempat dari hasil panennya, tergantung dari hasil panen, untuk membayar biaya peminjaman tanah tersebut (Bastin, 1954: 146-62).

Raffles menginginkan pajak tersebut bisa menggantikan kebijakan setor dan kerja wajib, dan penjualan tanah yang diterapkan oleh Daendels sebelumnya. Lebih lanjut Bastin berpendapat bahwa istilah 'land rent' sendiri digunakan pertama kali dalam sebuah laporan resmi pemerintah pada bulan April 1812 sebagai padanan dari konsep bahasa Jawa 'pajeg' (artinya pajak). Dalam pengertian aslinya, pajak tanah versi Raffles adalah sejumlah uang atau produk tertentu yang harus diserahkan paara petani kepada pemerintah sebagai bentuk pembayaran atas penggunaan dan pengolahan tanah. Meski demikian, penggunaan resmi istilah pajak tanah itu ditemukan dalam jurnal revenue Instruction edisi Februari 1814, yang didalamnya Raffles menjelaskan bahwa bentuk akhir dari pajak tanah itu akan didasarkan pada prinsip kepemilikan tanah yang bersifat individual (Bastin, 1954: 36-37).

Dengan menerapkan pajak tanah tersebut, Raffles berupaya untuk memperkenalkan sistem ekonomi perdagangan dan pertanian bebas, yang mengarah pada terciptanya tatanan sosial baru berisikan kelas petani independen, yang memiliki hak penguasaan yang jelas atas tanah yang digarapnya. Pendek kata, dia bermaksud membebaskan para petani dari cengkraman feudal kalangan elite priyayi. Dalam konteks waktu itu, hal itu merupakan sebuah ide revolusioner, yang bisa mengubah struktur sosial masyarakat Jawa. Namun demikian, pada kenyataannya Raffles menemukan idenya tersebut tidak bisa sepenuhnya berjalan tanpa bantuan dan kerjasama dengan struktur sosial yang ada; bahwa jika ingin menarik pajak tanah maka elit lokal harus dilibatkan. Selain itu, pemerintahan Raffles juga terhambat oleh tidak adanya pengetahuan yang akurat tentang sistem penguasaan tanah yang ada dan jumlah tanah subur yang tersedia. Dukungan administratif yang dibutuhkan, khususnya registrasi tanah dan survey kadastral sebagai basis penghitungan pajak, tidak tersedia. Penilaian pajak karenanya sangat tidak akurat, dan pemerintah tidak punya pilihan lain kecuali mengandalkan informasi dari para pejabat Jawa yang terbiasa menggunakan sistem pengukuran yang berbeda-beda dari satu daerah ke daerah lainnya. Rangkaian hambatan dan kesulitan tersebut telah 
menggagalkan eksperimen Raffles selama masa jabatannya yang singkat, meskipun dia dianggap berhasil dalam meletakan fondasi bagi penerapan pajak tanah di Jawa pada masa berikutnya oleh penguasa kolonial Belanda hingga empat dekade pertama abad keduapuluh (Hugenholtz, 1994: 148).

Pajak tanah, dengan demikian, merupakan salah satu jenis pajak kolonial yang paling lama diterapkan di Jawa (dan kemudian di wilayahwilayah Luar Jawa). Pajak ini sudah menjadi bagian esensial dari kebijakan fiskal sejak berdirinya negara kolonial Hindia Belanda pada awal abad kesembilanbelas hingga keruntuhannya di awal dekade kelima abad keduapuluh. Oleh karena itu, pajak tanah bisa dikatakan sebagai tulang punggung kebijakan politik ekonomi kolonial Belanda setelah Sistem Tanam Paksa, yang termasyhur karena keberhasilannya secara ekonomis namun juga karena dampak panjang sistem eksploitatif tersebut bagi perekonomian dan masyarakat Jawa secara keseluruhan. Ada dua hal yang menjelaskan makna penting pajak tanah bagi Pemerintah Hindia Belanda: pertama, pajak tanah diterapkan utamanya di Jawa, pusat konsentrasi demografi Hindia Belanda, kepada penduduk yang bekerja di sektor pertanian; kedua, pajak ini menjadikan tanah, faktor produksi terpenting dalam ekonomi agraris, sebagai obyek pajaknya, sehingga penerapannya menyangkut hajat hidup mayoritas penduduk di Hindia Belanda.

Meski demikian, cukup mengherankan bahwa historiografi tentang pajak tanah ini masih sangat terbatas jumlahnya. Satu-satunya kajian mendalam tentang pajak tanah pada masa kolonial adalah disertasi Hugenholtz di Universitas Leiden Belanda yang dipertahankan pada tahun 2008. Sebelumnya, Hugenholtz juga menulis sebuah artikel pendek pada tahun 1994 tentang reorganisasi pajak tanah di Jawa pada masa akhir kolonial. Karya-karya lainnya membahas pajak tanah secara sepintas lalu sebagai kebijakan kolonial dan karena keterkaitannya dengan sistem kepemilikan tanah dan pelaksanaan Sistem Tanam Paksa. Karya-karya tersebut diantaranya ditulis oleh Fokkens (1889, 1896, dan 1904), Kern (1904), Tang Sioe Tjhan (1933), Bastin (1954), Fasseur (1975), dan Elson (1993). Di kalangan sejarawan Indonesia, minat kajian tentang pajak tanah juga relatif tidak banyak berkembang, meskipun minat tentang persoalan-persoalan agrarian berkembang pesat. Sebagian besar kajian yang ada membahas pajak tanah sebagai sumber keresahan sosial dan gerakan protes di kalangan petani Jawa pada pertengahan abad kesembilanbelas hingga awal abad keduapuluh, seperti yang ditunjukan utamanya dalam karya Kartodirdjo $(1966,1975)$, Onghokham (1978, 1979), dan Wahid (2013), yang dalam salah satu bab disertasinya membahas sepintas lalu tentang penerapan pajak tanah di Jawa hingga awal abad keduapuluh.

Oleh karena itu, kajian tentang pajak tanah dan persoalan-persoalan yang terkait dengannya masih merupakan wilayah kajian yang relatif masih 
belum terjamah, sehingga dibutuhkan upaya-upaya serius untuk menggarap lahan penelitian yang 'terabaikan' tersebut. Artikel ini dimaksudkan untuk memberikan kontribusi terhadap kekosongan yang ada, dengan menjadikan Yogyakarta sebagai studi kasus. Permasalahan utama yang ingin dijawab adalah bagaimana pajak tanah diterapkan di wilayah vorstenlanden terutama setelah Pemerintah Kolonial Belanda berhasil merumuskan formulasi dan skema akhir pajak tersebut pada tahun 1907 dan bagaimana pajak tersebut mempengaruhi kondisi hidup masyarakat pedesaan di Yogyakarta. Yogyakarta dipilih dengan pertimbangan bahwa wilayah ini merupakan bagian dari vorstenlanden yang sejak berdirinya diberikan otonomi politik dan administrasi oleh Pemerintah Kolonial, yang awalnya pada awal abad kesembilanbelas dikecualikan dari kebijakan fiskal kolonial termasuk Sistem Tanam Paksa dan pajak tanah, tetapi kemudian menjadi bagian dari penerapan pajak tanah tersebut.

Untuk menjawab permasalahan tersebut artikel ini akan menggunakan pendekatan politik ekonomi, dengan menggabungkan informasi kuantitatif dan kualitatif yang dirangkum dari berbagai terbitan resmi pemerintah kolonial. Artikel ini akan menganalisa aspek kelembagaan dan administrasi perpajakan tersebut dan aspek ekonomi berupa jumlah pemasukan dan beban pajak yang harus dipikul penduduk Yogyakarta pada periode yang dikaji. Uraian akan dimulai dengan proses pencarian formula dan skema pajak tanah yang dilakukan Pemerintah Hindia Belanda sejak pertengahan abad kesembilanbelas, kemudian dilanjutkan dengan pengaturan administrasi di wilayah Yogyakarta sebagai bagian dari vorstenlanden, dan akhirnya ditutup dengan evaluasi tentang penerapan pajak tanah di wilayah ini.

\section{Mencari Format yang Tepat: Perubahan Administrasi Pajak Tanah}

Sesudah memperoleh kembali kekuasaannya atas Jawa, pemerintah kolonial Belanda berupaya memformulasikan ulang metode pengukuran pajak tanah disertai pengenalan sistem registrasi tanah baru. Anggota Komisi Penyiapan Negara Kolonial (1816-1819) mengajukan versi modifikasi mengenai pajak tanah melalui Surat Keputusan No.1 tanggal 9 Maret 1818, yang diikuti dengan versi revisinya satu tahun kemudian melalui SK No. 1 tanggal 4 Januari 1819. Versi yang kedua itulah yang kemudian dipertahankan dengan sedikit perbaikan hingga tahun 1872 (Boomgaard, 1989: 7). Peraturan tentang pajak tanah tahun 1819 itu mengakui bahwa tidak ada pengetahuan komprehensif mengenai sifat, kondisi dan produktivitas tanah-tanah subur di Jawa. Sebagai solusi, pemerintah kolonial memperkenalkan metode penilaian yang disebut admodiatie stelsel, melalui mana penetapan pajak tanah menjadi subyek negosiasi antara para kontrolir Belanda dengan para kepala desa. Meskipun sistem ini bersifat arbitrer, cenderung semena-mena, dan 
berpotensi menghasilkan perhitungan yang tidak adil, pemerintah kolonial mempertahankannya hingga akhir abad ke-19. Ahli administrasi kolonial, Clive Day (1904: 206) meyakini bahwa metode ini melahirkan inefisiensi dan kesewang-wenangan. Sistem tersebut dinilai rentan terhadap perilaku korupsi yang dalam jangka panjang bisa semakin menenggelamkan para petani Jawa ke dalam kemiskinan dan hutang kepada orang-orang Cina lintah darat, terutama ketika masa-masa sulit gagal panen.

Pemerintah kolonial menyadari potensi bahaya sistem ini dan karenanya mencoba untuk mengatasinya dengan melakukan survei dan mengumpulkan informasi tentang jenis-jenis tanah subur di seluruh Jawa. Survei pertama dilakukan di Kedu pada tahun 1819, kemudian diikuti di Rembang dan Cirebon, namun upaya tersebut gagal menghasilkan data yang akurat. Upaya selanjutnya dilakukan untuk memperbaiki sistem penarikan pajak tanah ini, namun harus berhenti karena meletusnya Perang Jawa pada tahun 1825 (Hugenholtz, 1986: 173). Sesudah situasi kembali aman di Jawa, pajak tanah kemudian sepenuhnya diadaptasikan untuk mendukung pelaksanaan sistem fiskal baru yang lebih ambisius, yaitu sistem penanaman 'paksa' (cultuurstelsel) yang mulai diberlakukan pada tahun 1830. Sejumlah sejarawan berpendapat bahwa 'pajak tanah berfungsi layaknya seperti hati untuk memanfaatkan bagian terpenting dari tenaga kerja dan tanah rakyat' (Van Niel, 1964: 358).

Tentang kaitan antara pajak tanah dan sistem tanam paksa, memang para sejarawan telah berbeda pendapat. Furnival (1944: 33-35) dan Day (1904: 280-281) memandangnya sebagai sejenis pajak ganda yang membebani para petani Jawa, dan merupakan sistem yang sangat eksploitatif. Dalam karyanya yang lebih kemudian, van Niel (1992) dan Breman (2010) mengkritik interpretasi tersebut dan menyebutnya sebagai sebuah kesalahfahaman, meskipun keduanya setuju bahwa kedua sistem tersebut memang sangat menindas. Dengan mengacu pada konsep aslinya, Van Niel menjelaskan kaitan antar kedua sistem tersebut sebagai berikut: para petani Jawa diminta untuk menanam seperlima dari tanahnya dengan komoditi ekspor, utamanya tebu dan indigo, dan harus menyerahkan panennya kepada pemerintah. Sebagai gantinya, para petani menerima sejumlah uang pembayaran yang disebut plantloon, yang dengannya mereka bisa membayar tagihan pajak tanah dari tanah yang mereka garap di desa masing-masing, dan pajak tersebut dihitung berdasarkan nilai dari komoditi ekspor yang ditanamnya. Pajak tanah tersebut, menurut Van Niel, tetap dihitung berdasarkan panen komoditi ekspor yang harus diserahkan; jika panennya melebihi nilai besaran pajak tanah yang harus dibayar, maka pemerintah akan mengembalikan kelebihan pembayaran pajak tanah itu. Dan sebaliknya, jika nilai panennya tidak mencukupi untuk menutup tagihan pajak tanah, maka seluruh desa harus membayar kekurangan tersebut dalam bentuk uang tunai 
atau barang (Van Niel 1992: 16-17). Oleh karena itu, kedua sistem fiskal tersebut terkait satu dengan yang lain, walaupun dalam prakteknya mereka dijalankan secara sangat berbeda dengan tingkat variasi yang tinggi baik pada tingkat lokal maupun regional.

Seiring menurunnya penghasilan dari Sistem Tanam Paksa yang kemudian secara bertahap dihapuskan pada awal tahun 1870, pemerintah kolonial harus mengandalkan pemasukannya dari sistem fiskal yang ada dan dari sumber non-pajak lainnya. Dalam kondisi demikian, pajak tanah kembali muncul sebagai pajak yang penting dan karenanya berbagai upaya dilakukan untuk meningkatkan kualitas penerapannya. Termasuk dilakukannya kembali upaya untuk mengumpulkan data-data yang lebih akurat tentang registrasi tanah dan statistik kadastral. Beberap survei dilakukan di sejumlah daerah pertanian penting di Jawa. Pada tahun 1851, pemerintah kolonial di bawah Gubernur Jenderal Duymaer van Twist melakukan sebuah pilot survei kadastral, bersamaan dengan sensus di karesidenan Cirebon. Upaya ini menandai apa yang kemudian dikenal sebagai Kadastraal Statistieke Opnamen (Survei Kadastral-Statistik). Survei pertama kali dilakukan di wilayah penghasil beras utama Indramayu dan kemudian di wilayah lain karesidenan Cirebon. Survei kemudian dilanjutkan di Karesidenan banyumas antara tahun 1858 dan 1863. Kedua survei tersebut berhasil mengumpulkan informasi yang bermanfaat, karenanya pemerintah kolonial memutuskan untuk melebarkan survei tersebut ke seluruh wilayah Jawa. Pada tahun 1789, semua survei kadastral dihentikan setelah mencakup sembilan karesidenan. Alasan penghentian tersebut dilaporkan adalah karena besarnya ongkos yang sudah dikeluarkan, kemajuan yang lamban, kekurangan personel, instrumen pengukuran yang tidak akurat, dan data yang dihasilkan kurang bisa diandalkan (Changing Economy Indonesia Vol. 10, 1990: 31).

Sementaraitu, Menteri Urusan Kolonial dan Gubernur Jenderal Hindia Belanda masih terus berbeda pendapat tentang penerapan pajak tanah di koloni. Polemik tersebut terus berlanjut hingga akhir 1860an, dan keduanya bersikuku pada pendapatnya masing-masing tentang bagaimana seharusnya pajak tanah diberlakukan: apakah ia seharusnya tetap diberlakukan sebagai pajak hasil panen ataukah dirubah menjadi pajak tanah sepenuhnya (Boomgaard, 1990: 116-17). Administrasi dan pengelolaan pajak tanah sedikit mengalami perbaikan ketika peraturan tentang pajak tanah yang baru dikeluarkan pada April 1872, dan secara resmi berlaku satu tahun kemudian. Peraturan baru ini dimaksudkan sebagai pengganti bagi peraturan tahun 1819, dan dijadikan standar bagi penetapan pajak tanah. Prinsip dasarnya adalah bahwa pajak tanah harus diterapkan pada semua sawah yang digarap oleh penduduk bumiputra. Untuk membuat ketentuan itu bisa berjalan, maka semua sawah objek pajak dibagi kedalam sejumlah kelompok, yang didasarkan pada hasil panen rata-rata padi per bau $( \pm 0.71$ hektar) selama 
tiga tahun sebelumnya. Klasifikasi dan penghitungan pajak tersebut akan bersifat tetap dan tidak berubah selama lima tahun dan, jikalau terjadi gagal panen atau keadaan khusus lainnya, maka pembebasan sebagian atau seluruh jumlah pajak yang harus dibayar akan diberikan. Namun demikian, peraturan baru ini gagal, dan tidak pernah bisa diterapkan. Masalahnya tetap sama: data lengkap tentang tanah yang menjadi obyek pajak tidak tersedia dan pegawai pemerintah yang professional tidak mencukupi untuk bisa menjamin penerapan pajak itu dengan baik (Hugenholtz, 1994: 162).

Persoalan pajak tanah (landrentekwestie) tersebut terus berlangsung hingga pertengahan dekade pertama abad ke-20, ketika pemerintah kolonial akhirnya mampu menghasilkan peraturan baru, yang dianggap bisa memberikan solusi terbaik terhadap permasalahan tersebut. Peraturan tersebut terinspirasi oleh cara pajak tanah dijalankan di Bali. Ujicoba peraturan baru tersebut dilakukan di Karesidenan Priangan dari tahun 1897 hingga 1906. Pada Januari 1907, Menteri Urusan Tanah Jajahan, J. Th. Cremer mengumumkan di depan Raad van Nederlandsch-Indië diberlakukannya Peraturan Pajak Tanah 1907 yang akhirnya mengakhiri sejarah panjang penuh liku penerapan pajak tanah di Jawa. Peraturan baru ini tidak serta merta diterapkan di seluruh Jawa, namun ia telah memenuhi semua persyaratan yang dibutuhkan dan penerapannya dilakukan secara bertahap distrik per distrik dan residen per residen. Antara 1897 dan 1906, peraturan tersebut diterapkan di 45 distrik di karesidenan Priangan, dan akhirnya pada tahun 1920 semua peraturan telah dijalankan di lebih dari 380 distrik di Jawa dan Madura (Hugenholtz, 2008: 283, 299).

Peraturan tahun 1907 menetapkan bahwa penilaian pajak tanah harus didasarkan pada pembedaan antara dua kategori tanah subur yang ditanami: sawah (tanah basah) dan huma (tanah kering, termasuk ladang, kebun, halaman, kolam, dan seterusnya). Untuk tanah kategori pertama, pajak tanah merupakan pajak atas hasil panen, sementara untuk tanah kategori kedua pajak tanah merupakan pajak atas kepemilikan tanah. Adapun alasan dipilihnya cara penilaian ini adalah karena pajak atas hasil panen bisa dibebaskan jika sawah mengalami gagal panen atau jika sawah dibiarkan tidak ditanami, sedangkan pajak untuk tanah kering harus dibayar setiap tahun apapun kondisi yang dialaminya. Tanah akan dinilai sebagai sebuah kesatuan, dianggap sebagai memiliki kualitas yang sama, dan pajak diterapkan secara individual pada setiap pemilik tanah. Penilaian ini tidak tetap selama sepuluh tahun dan karenanya hanya bisa direvisi sepuluh tahun kemudian. Besaran pajak yang harus dibayar setiap pemilik tanah adalah sedikitnya 8 sen dan paling besar 29 sen untuk tanah sawah, dan minimum 0.25 gulden dan maksimum 20 gulden per bau tanah kering (Hugenholtz, 1994: 144).

Keputusan tentang berapa pastinya persentase pajak yang akan 
diterapkan pada tanah sawah ditetapkan oleh desa (kepala desa) serta tergantung pada 'situasiperekonomian'. Berdasarkan situasi perkonomiannya, desa akan diklasifikasikan ke dalam satu dari tiga kelompok "wilayah pajak" (belastingkringen): lemah (jika persentase sawahnya antara 8-11\%), rata-rata (12-16\%) dan kuat (17-20\%). Untuk tanah kering, penilaian pajak dilakukan berdasarkan penilaian atas tanah sawah, karena tanah kering selalu dibandingkan dengan tanah sawah dan penilaian pajak akan diberlakukan pada dua wilayah yang kualitasnya kurang lebih sama (Hugenholtz, 2008: 285). Hasilnya adalah pajak tanah dikenakan dan diberlakukan pada wilayah pertanian produktif yang terus meluas, dan pendapatan pajak yang diperoleh darinyapun semakin meningkat tahun demi tahun. Pada tahun 1930, pemasukan tahunan dari pajak tanah mencapai jumlah tertingginya, yaitu sekitar 30 juta gulden, sebelum kembali jatuh ke level 20 juta gulden pada tahun 1940 .

Data tersebut menunjukan pentingnya pajak tanah sebagai salah satu sumber utama pendapatan keuangan negara kolonial. Selain itu, dari sudut pandanag politik, pajak tanah merupakan instrumen penting bagi negara kolonial untuk mengukur dan memelihara loyalitas dan kepatuhan penduduk serta pejabat bumiputra terhadap Pemerintah kolonial Hindia Belanda. Lalu bagaimana pajak tanah tersebut dipraktekan di wilayah vorstenlanden, di mana otoritas tradisional memiliki status penguasaan tanah yang khas, selain otonomi administratif? Apakah pemerintah kolonial memiliki kebijakan khusus, misalnya dengan mengecualikan wilayah tersebut dari penerapan pajak tanah sebagaimana halnya Sistem Tanam Paksa, ataukah tetap memberlakukan pajak tersebut namun dengan skema khusus, misalnya dengan membagi pendapatan pajak (tax revenue) dengan penguasa tradisional di wilayah tersebut? Bagian selanjutnya akan membahas pertaanyaan tersebut, namun terlebih dahulu akan diuraikan pengaturan administrasi kolonial secara umum dan tentunya administrasi pajak secara khusus untuk wilayah ini.

\section{Negara 'Tradisional' dan Administrasi Kolonial di Vorstenlanden}

Secara etimologis, istilah Bahasa Belanda vorstenlanden berarti tanah-tanah kerajaan. Dalam historiografi Indonesia dan utamanya dokumen-dokumen kolonial, istilah tersebut digunakan untuk menyebut wilayah bekas Kerajaan Mataram Islam. Melalui serangkaian peperangan sejak pertengahan abad ke-17 hingga awal abad ke-18, VOC (Vereenigde Oost-Indische Compagnie) berhasil mengalahkan kekuatan politik terakhir di Jawa tersebut pada tahun 1755. Melalui Perjanjian Giyanti, VOC mengambil alih sebagian besar wilayah bekas Kerajaan Mataram di pesisir utara, dan kemudian memecah wilayah inti kerajaan di pedalaman Jawa menjadi dua, yaitu Kasunanan Surakarta 
dan Kasultanan Yogyakarta. Dua tahun kemudian, VOC menyetujui Raden Mas Said (Mangkunegara I) untuk membentuk 'negara baru', Kadipaten Mangkunegara, di dalam wilayah Kasunanan Surakarta. Langkah ini kemudian diikuti oleh Thomas Raffles yang mendirikan 'negara baru' lainnya di Yogyakarta pada tahun 1813, yang dikenal kemudian sebagai Kadipaten Pakualaman. Dengan demikian, sejak pertengahan dekade kedua abad ke19 , istilah vorstenlanden digunakan untuk menyebut wilayah teritorial dari keempat 'negara tradisional Jawa' tersebut (Ricklefs, 1974; Houben, 1994: 4).

Keberhasilan Belanda memenangkan Perang Jawa (1825-1830) semakin memperkokoh posisi politik mereka atas Jawa, yang melapangkan jalan untuk menjalankan agenda politik ekonominya di pulau paling strategis di Nusantara ini. Guna menghindari konfrontasi dari kalangan elite Jawa, Pemerintah Belanda memutuskan untuk mengambil kebijakan politik secara hati-hati, utamanya tidak menganeksasi dan menghapuskan kerajaan-kerajaan Jawa tersebut melainkan memberikan otonomi kepada Para Penguasa Jawa untuk mengelola wilayahnya. Meskipun demikian, melalui serangkaian perjanjian di tahun-tahun awal sesudah berakhirnya perang Jawa, Pemerintah Belanda secara perlahan mengurangi wilayah kekuasaan mereka. Para Raja Jawa dipaksa untuk menyerahkan wilayahwilayah Mancanegara mereka kepada Pemerintah Kolonial untuk kemudian dijadikan sebagai wilayah administrasi kolonial, Karesidenan Kedu, Banyumas, Bagelen, Madiun dan Kediri. Wilayah kekuasaan Para Penguasa Jawa kini hanya tinggal bekas wilayah inti Kerajaan Mataram (Negaragung), yang terbentang antara gunung Merapi dan Gunung Lawu, utamanya kota Surakarta dan Yogyakarta (Houben, 1994: 5).

Bentuk kehati-hatian Pemerintah Kolonial terbukti dengan kesediaannya untuk memberikan kompensasi finansial kepada para Penguasa Jawa yang jumlah dan besarannya disesuaikan atau sebanding dengan nilai pemasukan yang diperoleh mereka dari wilayah yang diserahkan tersebut. Pada bulan November 1830, jumlah kompensasi finansial yang diusulkan untuk diberikan Pemerintah kolonial Belanda kepada Kraton Surakarta dan Yogyakarta atas pengambilalihan wilayah Kediri, Madiun, Bagelen, dan Banyumas adalah masing-masing sebesar $f 264.000$ dan $f 157.000$. Usulan tersebut disetujui satu tahun kemudian dengan jumlah kompensasi yang ternyata lebih besar. Untuk Kraton Yogyakarta uang kompensasi yang diberikan setiap tahun adalah sebesar $f$ 210.000. Selain itu, Kraton juga menerima pembagian hasil pengumpulan pajak burung walet, gerbang tol dan pajak pasar sebesar $f 255.000$ setiap tahunnya. Dengan demikian, total pendapatan tahunan Kraton Yogyakarta yang diperoleh dari Pemerintah Kolonial adalah sebesar $f 465.000$. Sementara itu, kompensasi yang diterima Kraton Surakarta sedikit lebih besar yaitu $f 754.987$ per tahun; dari jumlah tersebut $f 334.282$ merupakan kompensasi terhadap tanah wilayah yang 
diambil alih Pemerintah Kolonial Belanda (Houben, 1994: 63-64).

Kebijakan hati-hati Pemerintah Kolonial Belanda lainnya terhadap para Penguasa Jawa adalah berkaitan dengan kedudukan dan posisi politik mereka di wilayah bekas kerajaan Mataram tersebut. Sebagai pemenang Perang Jawa, Pemerintah kolonial Belanda bisa saja untuk menghapuskan semua peninggalan politik Mataram Islam, namun nyatanya mereka memilih untuk membiarkan pewaris-pewaris kerajaan tersebut untuk tetap hidup. Mereka bahkan kemudian mengakui klaim 'tradisional feodalistik' Rajaraja Jawa tersebut sebagai pemilik/penguasa tanah di wilayahnya masingmasing dan memberikan keleluasaan kepada para Raja Jawa tersebut untuk mengelola wilayahnya masing-masing sebagai wilayah semi-otonom. Meski demikian, Pemerintah Kolonial Belanda tetap melakukan pengawasan ketat dengan menempatkan perwakilannya di ibukota kedua kerajaan tersebut serta melakukan intervensi terhadap berbagai keputusan penting yang diambil Raja-raja Jawa tersebut, terutama untuk persoalan suksesi dan pertahanan (Van den Haspel, 1985: 139-142).

Selama periode Sistem Tanam Paksa (1830-1870), misalnya, Pemerintah Kolonial membebaskan wilayah vorstenlanden dan para petaninya dari kewajiban untuk menanam tanaman ekspor seperti wilayah-wilayah Jawa lainnya. Terkait dengan itu, Pemerintah Kolonial juga mengecualikan wilyah ini dari penerapan pajak tanah karena menghormati status Raja Surakarta dan Yogyakarta sebagai pemilik dan penguasa tanah di wilayahnya masing-masing. Meski demikian, selama periode yang sama, sistem penanaman komoditas ekspor sejenis STP juga di kembangkan di wilayah vorstenlanden ini oleh Raja dan keluarganya dengan menggandeng kalangan pengusaha swasta Eropa. Selain itu, sejumlah kebijakan fiskal Pemerintah Kolonial juga diterapkan kepada penduduk Karesidenan Yogyakarta dan Surakarta, terutama sewa pajak opium (opiumpacht), pajak penyembelihan hewan ternak dan babi, pajak perjudian, pajak penjualan minuman keras, pajak pasar, pajak pegadaian dan pajak penjualan burung walet. Untuk pajak opium, laporan kolonial di tahun 1860an menyebut Surakarta sebagai salah satu wilayah dengan pemasukan tertinggi di seluruh Jawa (Wahid, 2013: 94-95).

Pajak-pajak tersebut diberlakukan bersamaan dengan pajak-pajak dan sistem fiskal 'tradisional' lainnya yang memang sejak semula merupakan sumber pendapatan utama keraton Surakarta dan Yogyakarta. Sebagai pewaris kerajaan agraris, keraton Surakarta dan Yogyakarta menjadikan tanah dan segala yang ada di atasnya sebagai sumber pendapatan utama perekonomian mereka. Oleh karena itu, tidaklah mengejutkan ketika melihat kesuksesan Pemerintah Belanda dalam melakukan eksploitasi agraris berbasis struktur dan sistem sosial politik feodal pada tahun 1830 hingga 1870an, yang kemudian dikenal sebagai Sistem Tanam Paksa, Raja- 
raja Jawa juga melakukan strategi ekonomi yang sama di wilayahnya. Namun dikarenakan minimnya pengalaman dan kemampuan kewirausahaaan, maka sebagian besar dari mereka mewujudkan keinginan tersebut dengan menyewakan lahan/tanah yang dikuasainya kepada para pemodal Eropa atau bekerjasama dengan para pengusaha Tionghoa. Praktek tersebut sebenarnya sudah ada sejak zaman VOC namun menguat pada abad ke-19, seiring para raja dan bangsawan Jawa terdesak kebutuhan untuk membiayai gaya hidup 'grandeur' dan membayar hutang mereka kepada para pengusaha Tionghoa (Houben, 1994: 89-90).

Selama periode 1814 hingga 1821 saja, misalnya, di Surakarta dilaporkan sejumlah 166 petak lahan telah disewakan kepada pengusaha Eropa dan Tionghoa, sementara di Yogyakarta pada tahun yang sama jumlah lahan yang disewakan telah mencapai 115 jung. Perkembangan tersebut ternyata membuat khawatir Pemerintah Kolonial, karena dalam pandangan mereka peningkatan persewaan tanah tersebut bisa mendongkrak kekuatan ekonomi dan politik raja-raja Jawa selain bisa memperngaruhi kondisi kesejahteraan rakyat. Maka pada tahun 1823, Pemerintah kolonial mengeluarkan larangan bagi persewaan tanah melebihi tiga tahun di wilayah Praja Kejawen dan para bangsawan harus mengembalikan uang sewa yang telah mereka terima. Kebijakan tersebut menimbulkan kekecewaan mendalam di kalangan bangsawan tetapi juga para penyewa tanah; akibatnya mereka kemudian mendukung gerakan perlawanan yang dipimpin oleh Pangeran Dipanegara. Menyaksikan resistensi tersebut, Pemerintah Kolonial pada tahun 1827 mencabut larangan tersebut, dan mengizinkan kembali praktek persewaan tanah di wilayah-wilayah kerajaan Jawa tersebut, bahkan dengan ketentuan yang lebih menguntungkan para penyewa tanah, yaitu selama 20 tahun (Wasino, 2008: 30-31).

Selain menguasai lahan yang disewa, skema persewaan tanah yang berkembang juga memungkinkan para penyewa lahan untuk 'menguasai' para petani yang hidup di dalamnya. Oleh karena itu, para penyewa lahan selanjutnya memiliki keleluasaan tidak saja untuk mengolah lahan yang disewa tersebut, tetapi juga diberikan keleluasan untuk mengerahkan para petani yang ada sebagai tenaga pengolah lahan yang disewa. Sebagai ilustrasi, pada tahun 1837 seorang pengusaha Belanda J. Dezentje dilaporkan sebagai penyewa tanah terkaya di Solo dengan menyewa seluas 458 jung lahan dan berhak memakai tenaga 36.717 orang yang hidup di dalamnya. Dari praktek persewaan tanah tersebut, para pemilik tanah di Solo pada tahun 1821 misalnya dilaporkan memperoleh pendapatan sebesar $f$ 155,866. Di lahan-lahan sewaan tersebut selanjutnya para penyewa membudidayakan sejumlah tanaman ekspor - seperti komoditi yang dikembangkan dalam STP, yaitu utamanya kopi, tebu, indigo dan tembakau. Pada tahun 1864, Houben mencatat ada sekitar 115 perkebunan dengan luas lahan 198.881 
bau telah dikembangkan di Solo, menghasilkan 56.319 pikul kopi, 63.470 pikul tebu, 82.391 pikul indigo, dan 1.045 .152 pikul tembakau. Sementara itu, pada tahun 1862 di Yogyakarta tercatat ada 51 perkebunan menguasai lahan seluas 45.616 bau, dari mana dihasilkan 300 pikul kopi, 20.751 pikul tebu, 253.870 pikul indigo dan 1.853 pikul tembakau (Houben, 1994: 258, 262).

Padaumumnya, tanah-tanahyang disewakan tersebutadalah tanah yang berstatus lungguh atau apanage, yaitu tanah yang diberikan oleh raja kepada keluarga dan pembantunya, abdi-dalem (dari lurah hingga tumenggung) sebagai gaji atas status, pengabdian dan pekerjaan mereka dalam birokrasi kraton. Dalam konsep kekuasaan Jawa memang raja merupakan pemilik tanah, dan dia memiliki hak absolut untuk membagikan tanah-tanah di wilayahnya kepada siapa pun yang dikehendakinya. Mereka yang diberikan tanah lungguh disebut patuh, mereka selanjutnya menggandeng para bekel untuk mengolah tanah tersebut melalui sistem bagi hasil, bisa dibagi dua (maron) atau dibagi tiga (mertelu). Adapun ujung tombak pengolahan lahan berada di tangan para sikep atau petani penggarap sawah, yang umumnya merupakan penduduk di wilayah ka-bekel-an tersebut. Meski demikian, para bekel merupakan pemain terpenting dalam struktur produksi agraris di Jawa. Mereka memainkan peran sebagai perantara, brokerage, yang menjembatani pihak pemilik lahan dan pengolah lahan. Selain itu, mereka juga berperan sebagai pengumpul atau penebas pajak (sebagai bekti) yang harus disetorkan kepada patuh. Untuk itu, tidaklah mengherankan jika banyak diantara para bekel tersebut adalah kepala desa di tanah lungguh milik para bangsawan atau keluarga kraton (Margana, 2013: 2).

Maraknya persewaan tanah lungguh sejak tahun 1830an di wilayah Praja Kejawen memunculkan pemain baru yang disebut Bekel Putih, yaitu penyewa tanah berkebangsaan Eropa yang menyewa tanah untuk mengembangkan perkebunan komoditi ekspor. Pemain baru ini berfungsi sama halnya dengan bekel Jawa, yaitu sebagai penebas pajak; bedanya jika bekel Jawa mengumpulkan pajak dari sikep, para bekel putih tersebut membayar pajak atau sewa tanah dan menanggung semua kewajiban feodal sikep yang hidup di lahan sewaannya. Seringkali kewajiban feodal tersebut digantikan dengan uang, karena para bekel putih tersebut membutuhkan tenaga sikepnya untuk menyiapkan hingga memanen tanaman perkebunan mereka. Pada dekade kedua abad ke-20, dilaporkan bahwa bekel putih tersebut diberikan keleluasaan untuk mengembangkan perkebunan mereka dalam jangka panjang, karena mereka bisa menyewa tanah-tanah yang ada hingga 50 tahun lamanya. Beberapa studi menunjukan bahwa mereka lebih dipilih sebagai penyewa karena bersedia membayar uang sewa lebih besar dibanding kelompok lain, mereka bersedia memberikan bonus tambahan kepada para sikep dan patuh, dan mereka juga bersedia menanggung kewajiban- 
kewajiban feodal sebelumnya yang bisa digantikan dengan uang. Praktek dan sistem administrasi fiskal tersebut terus bertahan hingga berakhirnya kolonialisme Belanda di awala tahun 1940an (Margana, 2013: 5, 7).

\section{Pajak Tanah dan Pajak kolonial lainnya di Vorstenlanden}

Dari uraian terdahulu, jelas kiranya bahwa sewa tanah merupakan sumber pemasukan utama keraton-keraton Jawa sejak abad ke-18, namun semakin meluas sejak awal abad ke-19 ketika negara Kolonial Hindia Belanda mengambil alih kontrol atas wilayah vorstenlanden dan ekspansi kapitalis semakin menguat ke wilayah tersebut. Sebagai entitas politik yang diakui keberadaanya oleh penguasa kolonial, kraton-kraton Jawa diberikan status semi-independen dan kewenangan untuk mengelola wilayahnya masingmasing. Dari sudut pandang fiskal, pengakuan tersebut bermakna bahwa keraton dizinkan untuk melanjutkan sistem perpajakan 'tradisional' yang dasar-dasarnya sudah diterapkan sejak zaman Mataram Islam. Namun pada saat yang sama, para Penguasa Jawa juga harus rela menerima kebijakan fiskal kolonial diterapkan di wilayahnya, sebagai bentuk pengakuan dan 'ketundukan' mereka kepada negara kolonial yang berpusat di Batavia.

Pada akhir abad ke-18, sumber-sumber VOC menunjukan bahwa struktur perpajakan di wilayah Mataram terdiri atas pajak-pajak berikut ini: pajak tanah, pajak kepala, pajak usaha (dagang dan bisnis lainnya), pajak cukai, upeti, sewa lisensi pajak (pacht), dan pajak lainnya baik yang reguler maupun yang ireguler (Boomgaard, 1989: 22). Selain pajak-pajak uang tersebut, para petani Jawa di wilayah ini juga harus menanggung pajak dalam bentuk tenaga kerja (bekti) yang harus dipenuhi - meskipun tidak secara teratur. Beberapa bentuk bekti tersebut diantaranya adalah kerigaji, taker tedhak, gugur gunung dan pegaweyan. Sumber-sumber Belanda menyebut semua itu dengan satu label: heerendiensten yang sering diterjemahkan sebagai kerja wajib. Kewajiban kerja kerigaji (arti literernya penghormatan kepada penguasa) dilakukan secara reguler misalnya dalam bentuk pemeliharaan jalan, jembatan atau fasilitas umum lainnya dan di beberapa daerah kewajiban itu kadang-kadang bisa diganti dengan pembayaran uang (Carey and Hoadley, 2000: 344-48).

Diantara pajak-pajak yang ada, pajak tanah adalah pajak yang paling penting karena dikenakan kepada faktor produksi dan sektor ekonomi terpenting semua, serta harus dibayar oleh petani di semua wilayah kerajaan. Pajak tanah di Vorstenlanden diterapkan kepada semua jenis tanah dan hasil produksinya: sawah (tanah produktif beririgasi), tegalan (lahan produktif non-irigasi), dan pegagan (lahan kering yang ditanami tanaman berbeda). Selain itu, tanah pekarangan (kebun di sekeliling rumah) dan hasilnya juga terkadang masuk skema pajak ini. Pajak tanah (pajeg, pajeg sikep atau pajeg bumi) untuk lahan persawahan seringkali dibayarkan dalam bentuk padi 
atau hasil panen lain, namun di daerah pesisir pajak itu juga dibayar dengan uang yang besarannya disesuaikan dengan hasil panen, tergantung kualitas panenya bisa jadi sepertiga hingga separuh hasil panen. Di beberapa wilayah, pajak tambahan diterapkan pada lahan persawahan untuk dibayarkan kepada pejabat atau abdi-dalem yang tidak memiliki sawah bengkok. Pajak yang harus dibayar petani yang menggarap lahan tegalan dan pegagan umumnya lebih kecil dibanding pajak untuk lahan sawah, kira-kira sepersepuluh hingga sepertiga hasil panen, sementara pajak untuk lahan pekarangan dibayar dengan hasil tanaman yang dibudidayakan, misalnya kelapa, bambu atau lainnya (Boomgaard, 1989: 23).

Selain pajak tanah, pajak lain yang juga penting di wilayah Mataram ini adalah pajak cacah atau grabag dan pajak pacumpleng. Pajak yang pertama ditemukan di daerah pesisir utara sebagai semacam uang pengakuan atas hegemoni VOC yang harus diserahkan oleh para bupati. Besaran pajak dihitung berdasarkan jumlah cacah atau unit pajak di setiap kabupaten. ${ }^{1}$ Pajak pacumpleng (dari kata cumpleng yang artinya bukaan) atau pajak rumah harus dibayar oleh para sikep (petani penggarap) dalam bentuk barang, misalnya kain hasil tenunan. Selain itu, terapat pula semacam pajak bisnis yang disebut pajeg pangautan. Pajak ini dikenakan pada perdagangan berbagai jenis komoditi yang dihasilkan oleh tukang pandai besi, pengrajin kayu, pembuat tembikaer, penenun, pencelup kain, dan sebagainya; tetapi juga diterapkan pada penghasilan yang diperoleh dalang, penari, dan seniman lainnya. Besaran pajak ditetapkan sama di semua daerah, dan penghitungannya dilakukan berdasarkan pemasukan yang diperoleh atau kekayaan yang dimiliki para wajib pajak tersebut. Sebagai tambahan untuk setiap penyembelihan hewan ternak para petani juga harus membayar pajeg pambuntut dan di setiap perayaan hari besar keagamaan, seperti garebeg mulud, slametan atau sedekah para petani juga diharapkan untuk menyumbangkan tenaga atau hasil panennya (Carey, 2007: 57; Boomgaard ,1989: 24).

Selain pajak-pajak atas alat-alat produksi dan hasil produksi, pada pergantian abad ke-19 keraton-keraton Jawa juga mulai menerapkan pajak konsumsi dan pajak jalan raya dan pasar. Pajak-pajak baru ini dikumpulkan melalui sistem sewa lisensi pajak (pachtstelsel), yang sebelumnya telah dikembangkan VOC di Batavia dan wilayah lain kekuasaannya. Pajak konsumsi terbesar adalah pajak opium, sedangkan pajak lainnya adalah pajak tol jalan raya dan pajak pasar. Dari skema pajak tersebut, dilaporkan bahwa pada awal abad ke-19 pihak Kasultanan dan Kasunanan menerima sekitar 40 persen dari pemasukan yang diperoleh dan sisanya dikirim ke bendahara

1) Kata cacah arti literernya adalah unit penghitungan (Nagtegaal, 1996: 48), namun sebagai istilah untuk pengukuran fiskal maknanya berbeda-beda. Menurut Boomgaard (1989: 207-13), istilah tersebut setidaknya memiliki tiga makna, yaitu: 1) sebuah keluarga atau rumahtangga yang terdiri dari 4-6 jiwa;2) sebuah unti pajak; dan 3) sebuah istilah yang mengacu pada sepetak lahan produktif. 
kolonial di Batavia. Khusus untuk pajak opium, proses pengumpulannya melibatkan orang tionghoa dan pejabat birokrasi rendahan, terutama mantri desa dan bekel, sedangkan di wilayah administrasi kolonial proses pengumpulan pajak yang sama sepenuhnya dilakukan oleh para penyewa pajak (pachter) dengan dibantu oleh peagawai sewaaannya (Van Niel, 2005: 56; Wahid, 2013: 60).

Sebagian besar dari skema perpajakan tradisional tersebut tetap dipertahankan oleh Praja Kejawen hingga akhir periode kolonial. Selama periode Sistem Tanam Paksa (STP), wilayah-wilayah kerajaan memang dikecualikan dari penerapan pajak tanah kolonial, yang di wilayah gubernemen keberadaaan dan penerapannya menjadi basis bagi STP. Meski demikian, pajak tanah lokal diberlakukan oleh pihak kerajaan dan penerapannya diintegrasikan dengan sistem sewa tanah dengan pihak swasta. Jadi, para petani tetap dibebani kewajiban untuk membayar pajak tanah sebagai bentuk pembayaran atas hak hidup di tanah tersebut. Bedanya, sesudah tanah mereka disewa oleh pihak swasta Eropa mereka menunaikan kewajiban pajaknya bukan kepada pejabat keraton pemilik tanah, melainkan kepada penyewa tanah tersebut. Seringkali pajak tanah tersebut dibayarkan dalam bentuk kerja wajib untuk mengolah tanah, memelihara tanaman, memanen dan kemudian membawa hasil panen ke pusat pengolahan terdekat (terutama tebu dan industri gula). Mekanisme inilah yang menopang berkembangnya sektor perkebunan tanaman ekspor di wilayah Surakarta dan Yogyakarta (Wasino, 2008; Margona, 2013).

Sementara itu, pada level 'nasional' pajak tanah pasca berakhirnya STP menjadi semakin penting maknanya sebagai sumber keuangan negara kolonial. Hal ini didukung dengan perluasan penerapan pajak tanah ke luar Jawa sejak akhir abad ke-19 seiring dengan roerientasi kebijakan ekonomi kolonial mengarah pada pengembangan sektor-sektor ekonomi baru di Sumatra, Kalimantan dan Sulawesi. Dukungan infrastruktur juga diberikan melalui perbaikan sistem administrasi dan pengelolaan pajak tanah guna mendukung peningkatan efisiensi dan efektivitasnya. Grafik 1 menunjukan peningkatan pendapatan negara kolonial dari pajak tanah dari waktu ke waktu. Sayangnya data statistik yang lebih komprehensif dan mendetail tentang pemasukan pajak tanah pada tingkat lokal, termasuk wilayah Yogyakarta dan Surakarta belum tersedia. Data yang tersedia masih relatif terbatas dan hanya bisa ditemukan dalam catatan dan laporan pemerintah yang terpisah-pisah. Diperlukan upaya serius dalam jangka panjang untuk bisa mengkodifikasi data-data statistik tentang pajak tanah di seluruh wilayah nusantara (Hugenholtz, 2008).

Khusus di wilayah Yogyakarta, pada awal abad ke-20, terjadi perkembangan penting berkaitan dengan sistem kepemilikan tanah Kesultanan yang kemudian diikuti penyesuaian fiskal terkait dengannya. 


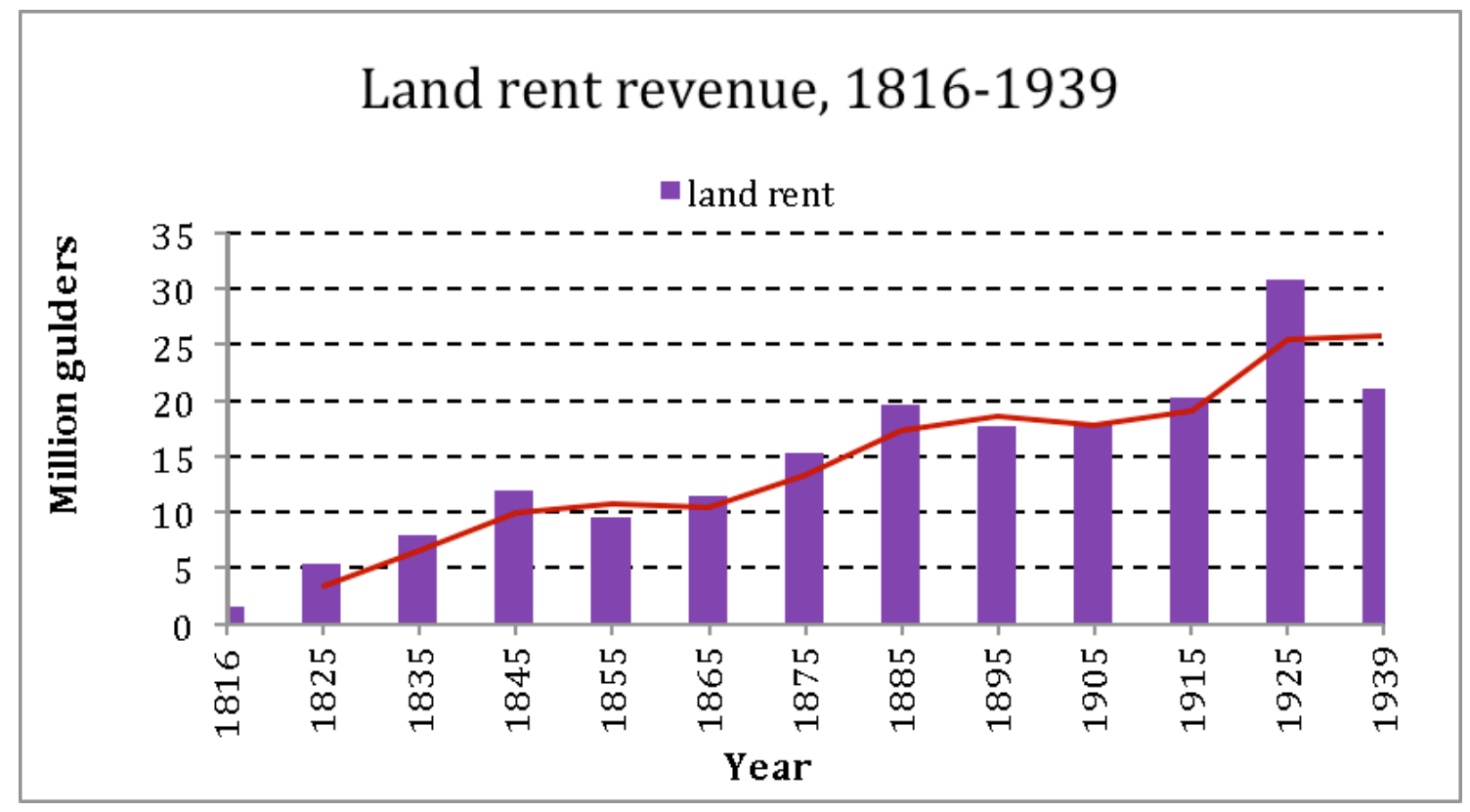

Figur 1.

Pemasukan Pemerintah dari Pajak Tanah, 1816-1940

Sumber: Mellegers (2004), online database of the International Institute of Social History (IISG) in Amsterdam: www.iisg.nl/indonesianeconomy/, accessed 25

October 2012. Dimodifikasi dari Abdul Wahid (2013).

Kebijakan tersebut dikenal sebagai reorganisasi tanah, dimulai pada tahun 1917 dan berjalan lambat hingga tahun 1925. Melalui kebijakan tersebut, secara perlahan Sultan mengambil kembali semua tanah apanage (lungguh), yang sebelumnya diberikan kepada para pejabat kerajaan dan sebagai gantinya mereka kemudian menerima gaji dalam bentuk uang. Para priyayi tersebut masih memiliki tanah tapi hanya untuk tempat tinggal saja dan bukan lahan produktif untuk disewakan secara komersil. Selanjutnya, reorganisasi tanah tersebut juga mengubah secara fundamental sistem kepemilikan tanah dalam lingkup yang lebih luas, karena memungkinkan penduduk dan masyarakat biasa untuk memperoleh status baru kepemilikan tanah. Sebelumnya para abdi-dalem dan penduduk lainnya hanya memiliki hak pakai tanah, namun setelah reorganisasi tersebut mereka bisa memilik tanah dengan status hak milik (andarbe). Artinya mereka kini bisa menempati, mengelola dan mengambil keuntungan dari tanah miliknya tersebut (Setiawati, 2011: 114115).

Konsekuensi langsung dari perubahan status kepemilikan tanah tersebut adalah para pemilik tanah harus mendaftarkan tanah miliknya ke kantor pendaftaran tanah di kraton (kantor mangeti seti) dan kemudian membayar secara rutin pajak kepemilikan tanah, verponding, kepada kraton 
(Sultan). Pajak ini berbeda dengan pajak sewa tanah yang sebelumnya sudah lama dikembangkan kraton Yogyakarta kepada para penyewa tanah Eropa. Pajak tanah baru ini diterapkan kepapda semua penduduk yang terdaftar memiliki tanah di wilayah Kasultanan Yogyakarta, terutama di Kota Yogyakarta. Pajak verponding tersebut harus dibayarkan dua kali dalam setahun, yaitu setiap tanggal 1 Juni dan 1 November. Denda akan dikenakan kepada mereka yang gagal memenuhi kewajibannya, yaitu sebesar $f 5$ untuk setiap obyek pajak senilai $f 100$. Besaran pajak ditetapkan oleh sebuah tim yang ditunjuk keraton dengan berkonsultasi kepad residen Yogyakarta dengan mempertimbangkan nilai ekonomis tanah bersangkutan, harga jual dan sewa tanah dan rumah diatasnya (Rijksblaad van Sultanaat Djogjakarta no. 24 tahun 1925; Setiawati, 2011: 99).

Peraturan Sultan tersebut, menentukan bahwa besaran pajak untuk tanah pekarangan yang ada rumahnya adalah sebesar $f 7,5$ untuk setiap nilai ekonomi sebesar $f 100$ atau setiap harga sewa rumah sebesar $f 120$. Untuk sewa rumah seharga f 60 hingga $f 120$ diwajibkan membayar pajak sebesar $f 5$ setiap kelipatan $f 100$ dan apabila harga sewanya kurang dari $f 60$, maka pajak yang harus dibayar adalah sebsar $f 2$ untuk setiap $f 100$. Untuk tanah pekarangan tanpa rumah jika nilai jualnya berkisar antara $f 600$ hingga $f$ 1200, maka nilai pajaknya adalah sebesar $1 / 5$ atau $f 20$ untuk setiap $f 100$. Sementara itu, orang-orang non-pribumi (Tionghoa, Arab, India, Eropa, dsb.) diizinkan untuk menggunakan dan memanfaatkan tanah dengan status sebagai hak pakai dan hak opstal (mendirikan bangunan) paling lama 30 tahun. Jika mereka menempati tanah pekarangan tanpa hak eigendom maka mereka diwajibkan untuk membayar pajak sebesar $f 2$ atau 2\% dari harga tanah (Rijksblaad van Sultanaat Djogjakarta, No. 5, 1925; Setiawati, 2011: 99).

Hak pakai tanah tersebut hanya diberikan untuk tanah yang tidak luas, yang hanya cukup untuk mendirikan tempat tinggal. Penduduk dan wajib pajak yang tidak mampu membayar pajak akan kehilangan haknya dan harus meninggalkan tanah yang mereka tempati. Studi Setiawati (2011: 101104) mengungkapkan sejumlah kasus penunggakan pajak verponding yang melibatkan pengusaha Eropa dan Tionghoa yang harus diselesaikan secara hukum pada akhir 1920an. Nampaknya kondisi ekonomi waktu itu yang terdampak Depresi Ekonomi 1930 turut mempengaruhi kemampuan para wajib pajak untuk menunaikan kewajibanya. Pajak bumi atau tanah memang menunjukan penurunan di tahun-tahun menjelang 1930, meskipun pajak yang lain justru menunjukan peningkatan. Naik turun pendapatan pajak yang diterima Kasultanan Yogyakarta di Kota Yogyakarta bisa dibaca dalam Tabel 1 berikut. 


\begin{tabular}{|l|c|c|c|c|c|c|}
\hline \multicolumn{1}{|c|}{ Jenis Pajak } & $\mathbf{1 9 2 5}$ & $\mathbf{1 9 2 6}$ & $\mathbf{1 9 2 7}$ & $\mathbf{1 9 2 8}$ & $\mathbf{1 9 2 9}$ & $\mathbf{1 9 3 0}$ \\
\hline Pajak Bumi & 723.180 & 723.500 & 680.500 & 553.000 & 209.000 & 219.000 \\
\hline Verponding & 43.800 & 43.500 & 43.800 & 43.800 & 43.000 & 30.000 \\
\hline Recht van Opstal & 56.124 & 48.500 & 23.500 & 48.500 & 122.700 & 123.000 \\
\hline Sewa Rumah & - & 12.708 & 12.288 & 12.660 & 19.956 & 18.393 \\
\hline Sewa Tanah Sultan & 28.800 & 19.200 & 19.338 & 19.338 & 20.200 & 22.500 \\
\hline
\end{tabular}

Tabel 1.

Pendapat Pajak Kesultanan Yogyakarta di Kota Yogyakarta, 1925-1930 (dalam gulden).

Sumber: Direproduksi dari Setiawati (2011: Tabel 8, hlm. 104).

Sejauh mana perkembangan yang terjadi di wilayah Kesultanan Yogyakarta tersebut juga terjadi di wilayah Kasunanan Surakarta belum diketahui secara persis. Berdasarkan data-data statistik pemerintah kolonial yang sejauh ini berhasil ditemukan, Kasunan Surakarta juga menerapkan skema perpajakan yang sama, meskipun reorganisasi pemilikan tanah milik raja tidak dilakukan seperti yang dilakukan di Yogyakarta. Namun dari sudut pandang pemerintah kolonial, posisi Karesidenan Surakarta sebagai sumber pendapatan pajak secara umum lebih penting dibandingkan Yogyakarta. Surakarta memiliki jumlah perkebunan lebih banyak dan cakupan wilayah produktifnya lebih besar dibandingkan Yogyakarta.

\section{Kesimpulan}

Dari uraian di atas, nampak jelas bahwa pajak tanah merupakan instrumen fiskal utama, baik dalam struktur administrasi tradisional di Kasunanan Surakarta dan Kasultanan Yogyakarta, maupun dalam struktur administrasi negara kolonial. Posisi dan status politik kedua wilayah kerajaan Jawa yang unik dalam tatanan politik negara Hindia Belanda berimbas pada pelaksanaan penerapan pajak tanah dan pajak-pajak lainnya. Di bawah struktur administrasi kerajaan, di mana raja dan keluarganya merupakan pemilik utama tanah, pajak tanah menjadi satu paket dengan praktek penyewaan tanah kepada pihak swasta Eropa atau Tionghoa, yang didalamnya para petani wajib pajak membayarnya dalam bentuk kerja wajib bagi perkebunan milik penyewa tanah atau dalam bentuk barang hasil produksi pengolahan tanahnya. Sementara di bawah administrasi negara kolonial, pajak tanah ditunaikan dengan pembayaran uang sebagai kompensasi atas izin yang diberikan negara kepada pemilik tanah untuk menempati dan mengelolanya. Dengan demikian, dalam prakteknya di wilayah vorstenlanden administrasi pajak tanah mengandung unsur dualisme, antara sistem tradisional peninggalan Mataram dan sistem kolonial yang diformulasikan sejak 
awal abad ke-19. Sejauh mana dualisme administrasi tersebut membebani penduduk petani di kedua wilayah tersebut, masih memerlukan penelitian lebih lanjut terhadap sumber-sumber sejarah yang ada.

\section{Referensi}

Abdul Wahid (2013). "From Revenue Farming to State Monopoly: The Political Economy of Taxation in Colonial Indonesia, Java 1816-1942", PhD Thesis. Netherlands: Utrecht University.

Bastin, J. (1954). Raffles' Ideas on the Land Rent System in Java and the Mackenzie Land Tenure Commission. 's-Gravenhage: Martinus Nijhoff.

Boomgaard, P. (1989). Children of the Colonial State: Population Growth and Economic Development in Java, 1795-1880, CASA Monograph No.1. Amsterdam: Free University Press, Centre for Asian Studies.

(1990). Between Sovereign Domain and Servile Tenure: the Development of Rights to Land in Java, 1780-1870, Comparative Asian Studies No. 4. Amsterdam: Free University Press.

Booth, Anne (1998). The Indonesian Economy in the Nineteenth and Twentieth Centuries: A History of Missed Opportunities. London (etc.): MacMillan and New York: St. Martin's Press.

Breman, J. C. (2010). Koloniaal Profijt van Onvrije Arbeid: Het Preanger Stelsel van Gedwongen Koffieteelt op Java, 1720-1870. Amsterdam: Amsterdam University Press.

Carey, P. (2007). The Power of Prophecy: Prince Dipanegara and the End of an Old Order in Java, 1785-1855. Leiden: KITLV Press.

Carey, P. and Mason Hoadley (eds.) (2000). The Archive of Yogyakarta: An edition of Javanese reports, letters and land grants from the Yogyakarta court dated between A.J. 1698 and A.J. 1740 (1772-1813) taken from materials in the British Library and the India Office Library (London), Vol.2: Documents related to economic and agrarian affairs. Oxford [etc.]: Oxford University Press.

Changing Economy Indonesia, Vol. 10 (1990). Amsterdam: Koninklijke Instituut voor Tropen.

Day, C. (1904). The Policy and Administration of the Dutch in Java. New York: The Macmillan Press.

Elson, R. (1993). Village Java under the Cultivation System, 1830-1870. Sydney: ASAAAllen \& Unwin.

Fasseur, C. (1992). The Politics of Colonial Exploitation: Java, the Dutch and the Cultivation System. Ithaca: Southeast Asian Program, Cornell University.

Fokkens, F. (1914). De Afschaffing der Laatste Heerendiensten op Java. Hollandia: Barn. (1992). "Plea for tighter controls on Chinese revenue farming and immigration”, in: M.R. Fernando \& David Bulbeck (eds.), Chinese Economic Activity in Netherlands India: selected translations from the Dutch. Singapore: Institute of Southeast Asian Studies.

Furnival, J.S. (1944). Netherlands India: A Plural Economy. Oxford: Oxford University Press.

Haspel, C.Ch. Van den (1985). Overwicht in Overleg: Hervorming van Justitie, Grondgebruik en Bestuur in de Vorstenlanden op Java, 1880-1930. Dordrecht 
[etc.]: KITLV-Foris Publication.

Houben, Vincent J.H. (1994). Kraton and Kumpeni: Surakarta and Yogyakarta, 18301870. Leiden: KITLV Press.

Hugenholtz, W. R. (1994). 'The Landrent Question and its Solution, 1850-1920', in Robert Cribb (ed.), The Late Colonial State in Indonesia: Political and Economic Foundation of the Netherlands Indies, 1880-1942. Leiden: KITLV Press. (2008). "Landrentebelastingt op Java, 1812-1920", PhD Dissertation. Leiden: Leiden University.

Sri Margana dkk. (2013). Praktek Persewaan Tanah Lungguh di Kesultanan Yogyakarta Pada Masa Sultan Hamengku Buwono VII Tahun 1877-1921. Yogyakarta: Badan Perpustakaan dan Arsip Daerah DI Yogyakarta.

Niel, Robert van (1992). Java under the Cultivation System: Collected writings. Leiden: KITLV Press.

(2005). Java's NortheastCoast, 1740-1840:A Study in Colonial Encroachment and Dominance. Leiden: CNWS publication.

Nur Aini Setiawati (2011). Dari Tanah Sultan Menuju Tanah Rakyat: Pola Pemilikan, Penguasaan, dan Sengketa Tanah di Kota Yogyakarta Setelah Reorganisasi 1917. Yogyakarta: STPN Press.

Raffles, T.S. (1817). The History of Java. London: Black, Parbury and Allen.

Rijksblaad van Sultanaat Djogjakarta, No. 5, tahun 1925.

Rijksblaad van Sultanaat Djogjakarta no. 24 tahun 1925.

Waal, E. de (1865). Aanteekeningen over Koloniale Onderwerpen, Vol. I-IV: De Opiumpacht of Java.'s-Gravenhage: Martinus Nijhoff.

Wasino (2008). Kapitalisme Bumiputra: Perubahan Masyarakat Bumiputra. Yogyakarta: LKIS. 